\title{
PEMILIHAN ALTERNATIF SUMBER AIR BAKU DI KABUPATEN KARO
}

\author{
Salomo Simanjuntak ${ }^{1)}$, Yetty Riris Saragi ${ }^{2)}$, Johan Oberlyn Simanjuntak ${ }^{3)}$, \\ Humisar Pasaribu ${ }^{4}$, Ricki A H Sianipar ${ }^{5}$ ) \\ Fakultas Teknik Universitas HKBP Nommensen, Medan \\ Email: salomojuntak679@yahoo.co.id ${ }^{1}$, yettyririssaragi@yahoo.com ${ }^{2}$, \\ oberlyn.simanjuntak@yahoo.co.id ${ }^{3}$, pasaribu.humisar@yahoo.com ${ }^{4}$
}

\begin{abstract}
Clean water is a primary need for humans in every country. The availability of clean water must be guaranteed in time, quantity and quality. The need for water for both domestic and nondomestic needs continues to increase from year to year. To meet the needs of clean water, the people of Karo Regency need clean water sources that are suitable for drinking.

Water resources are water discharge and population for water distribution. In finding the amount of water demand, an analysis of the population and analysis of clean water production is carried out. Determining the need for clean water and the population in Karo Regency uses the Geometry method which this method shows the largest population growth so that it can be planned for clean water needs until 2027.

Based on the results of the projected population plus the number of water needs in 2027 as many as 491,444 people, the required water discharge is 907,799 l/s while the current production capacity is 14,744.831 l/s, so the additional capacity needed is $0.01003 \mathrm{m3} / \mathrm{s}$.

Implementation in the construction of clean water facilities must be adjusted to the level of social, cultural, and economic conditions of the community.
\end{abstract}

\section{Keywords : Water Debit, Water Availability, Population}

\section{PENDAHULUAN}

Air merupakan sumber daya yang sangat diperlukan oleh makhluk hidup baik untuk memenuhi kebutuhan maupun menopang hidup secara alami. Kegunaan air yang bersifat universal atau menyeluruh dari setiap aspek kehidupan menjadi semakin berharganya air baik jika dilihat dari segi kuantitas maupun kualitas.

Semakin tinggi taraf kehidupan seseorang,maka kebutuhan air akan meningkat. Air adalah senyawa yang penting bagi semua bentuk kehidupan yang diketahui sampai saat di bumi.sehingga dapat disimpulkan bahwa sumber daya air di muka bumi ini tidak akan bertambah jumlahnya.Di lain pihak,air menjadi kebutuhan penting bagi kehidupan makhluk hidup,khususnya kebutuhan akan air bersih.

Received, 22 ${ }^{\text {rd }}$ April 2021; 28 $8^{\text {th }}$ May Revised, 2021; Accepted July, 2021 
Penelitian ini menganalisis dan memprediksi banyaknya kebutuhan air bersih untuk kondisi sekarang dan untuk kebutuhan dimasa yang akan datang di kabupaten karo provinsi sumatera utara,dimana agar kebutuhan air bersih dapat terpenuhi yang diperlukan kebijakan pengelolahan yang menyeluruh dan mencakup pengaturan perlindungan atas sumber daya air. Kebutuhan air sangat perlu di analisis untuk memperoleh kesiapan data dan informasi tentang air bersih serta jumlah kebutuhan air bersih disuatu daerah aliran sungai yang lengkap dan akurat. tujuan dari penulisan yaitu untuk menghitung jumlah kebutuhan air bersih pada kondisi sekarang dan memprediksi kebutuhan air untuk kondisi 10 tahun yang akan datang di Kabupaten Karo, Sumatera Utara.

\section{TINJAUAN PUSTAKA}

\section{A. Proyeksi Pertumbuhan Jumlah Penduduk}

Kebutuhan air bersih merupakan masalah masa sekarang dan masa depan, maka besarnya kebutuhan air besih perlu di prediksi. Akan tetapi, sebelum memprediksi besarnya kebutuhan air bersih, jumlah penduduk dimasa yang akan datang harus di prediksi terlebih dahulu.

\section{A.1 Metode Proyeksi Penduduk Aritmatika}

Metode ini biasanya disebut juga dengan rata-rata hilang. Rumus metode ini adalah

$$
\text { Pn }=\text { Po }(1+(r \% . n))
$$

Dimana :

Pn = Jumlah penduduk pada tahun ke-n (jiwa)

$\mathrm{Pt} \quad=$ Jumlah penduduk yang diketahui pada tahun I

Po = Jumlah penduduk yang diketahui pada tahun akhir

$\mathrm{n} \quad=$ Jumlah interval

$\mathrm{t} \quad=$ Jumlah tahun yang diketahui

\section{A.2 Metode Proyeksi Penduduk Geometrik}

Untuk keperluan proyeksi penduduk, metode ini digunakan bila data menunjukkan peningkatan yang pesat dari waktu ke waktu.

$$
\operatorname{Pn}=\operatorname{Po}(1+r)^{n}
$$

Dimana :

Pn $\quad=$ Jumlah penduduk pada tahun $\mathrm{n}$ 


$$
\begin{array}{ll}
\mathrm{Po} & =\text { Jumlah penduduk pada tahun awal } \\
\mathrm{r} & =\text { Angka pertumbuhan penduduk } \\
\mathrm{n} & =\text { Periode waktu dalam tahun }
\end{array}
$$

\section{A.3 Metode Least-square}

Metode ini umumnya digunakan pada daerah yang tingkat pertambahan penduduk cukup tinggi.

$$
\begin{aligned}
& \mathrm{Y}=\mathrm{a} . \mathrm{X}+\mathrm{b} \\
& \text { Dimana : } \\
& \mathrm{Y} \quad=\text { nilai variabel berdasarkan garisegresi } \\
& \mathrm{X} \quad=\text { variabel independen } \\
& \mathrm{a} \quad=\text { konstanta } \\
& \mathrm{b} \quad=\text { koefisien arah regresi linear }
\end{aligned}
$$

\section{B. KEBUTUHAN AIR BERSIH}

\section{B.1 Standar Penyediaan Air Domestik}

Standar Penyediaan Air domestik ditentuka oleh jumlah konsumen domestik yang dapat diketahui dari data penduduk yang ada. Standar penyediaan kebutuhan domestik ini meliputi minum, mandi, masak, dan lain-lain.

Semakin banyak jumlah orang, semakin banyak pula kebutuhan air. Sebagai contoh pengaruh jumlah penduduk terhadap jumlah kebutuhan air dapat dilihat pada grafik berikut

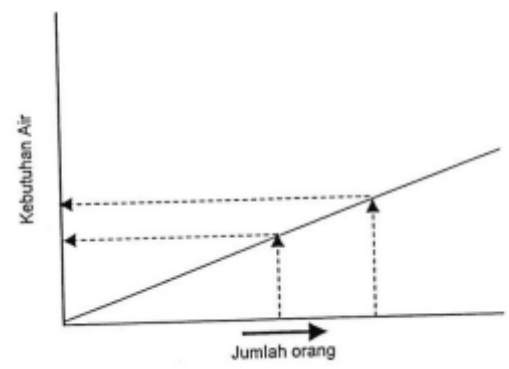

Gambar 1. Pengaruh pertumbuhan penduduk terhadap jumlah kebutuhan air Kebutuhan air domestik untuk kota dibagi dalam beberapa kategori, yaitu :

- Kota kategori I (Metropolitan )

- Kota kategori II ( Kota Besar )

- Kota kategori III ( Kota Sedang ) 
Jurnal Visi Eksakta (JVIEKS)

Vol.2, No.2, Juli 2021, pp. 225-238

https://ejournal.uhn.ac.id/index.php/eksakta

- Kota kategori IV ( Kota Kecil )

- Kota kategori V ( Desa ).

Untuk mengetahui kriteria perencanaan air bersih pada tiap-tiap kategori dapat dilihat pada tabel berikut ini :

Tabel 1. Kriteria Perencanaan Air Bersih

\begin{tabular}{|c|c|c|c|c|c|}
\hline \multirow{3}{*}{ URAIAN } & \multicolumn{5}{|c|}{$\begin{array}{l}\text { KATE GORI KOTA BERDASARKAN JUML AH PENDUDUK } \\
\text { (JWA) }\end{array}$} \\
\hline & $\$ 1.000 .000$ & $\begin{array}{l}500.000 \\
\text { sid } \\
1.000 .000\end{array}$ & $\begin{array}{l}100000 \\
s 00000 \\
50000\end{array}$ & $\begin{array}{c}20.000 \\
=2 / d \\
100.000\end{array}$ & $<20000$ \\
\hline & $\begin{array}{c}\text { Kota } \\
\text { Metropolitan }\end{array}$ & $\begin{array}{l}\text { Kota } \\
\text { Besar }\end{array}$ & $\begin{array}{c}\text { Kota } \\
\text { Sedang }\end{array}$ & $\begin{array}{l}\text { Kota } \\
\text { Kecil }\end{array}$ & Desa \\
\hline 1 & 2 & 3 & 4 & 5 & 6 \\
\hline $\begin{array}{l}\text { 1. Konvuns i Unit Sambungan } \\
\text { Rumah (S R) ( literlorz/hari) }\end{array}$ & $=150$ & $150-120$ & $90-120$ & $80-120$ & $60-80$ \\
\hline $\begin{array}{l}\text { 2. Konsurwi Unit Hidman (HU) } \\
\text { ( literfor/hari) }\end{array}$ & $20-40$ & $20-40$ & $20-40$ & $20-40$ & $20-40$ \\
\hline 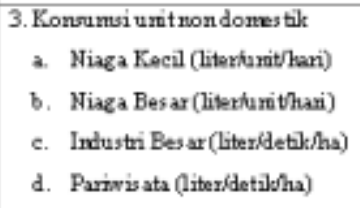 & $\begin{array}{c}600-900 \\
1000-5000 \\
0.2-0.8 \\
0.1-0.3\end{array}$ & $\begin{array}{c}600-900 \\
1000-5000 \\
0.2-0.8 \\
0.1-0.3\end{array}$ & & $\begin{array}{c}600 \\
1900 \\
0.2-0.8 \\
0.1=0.3\end{array}$ & \\
\hline 4. Kehlangan Air ( \%) & $20 \cdot 30$ & $20 \cdot 30$ & $20-30$ & $20-30$ & $20-30$ \\
\hline S. Faltor Hari Mabs imum & $\begin{array}{l}1.15-1.25 \\
* \text { harian }\end{array}$ & $\begin{array}{l}1.15-1.25 \\
* \text { harian }\end{array}$ & $\begin{array}{l}1.15-1.25 \\
* \text { harian }\end{array}$ & $\begin{array}{l}1.15-1.25 \\
* \text { harian }\end{array}$ & $\begin{array}{l}1.15-1.25 \\
\text { *harian }\end{array}$ \\
\hline 6. Faltor Jam Purcak & $\begin{array}{l}1.75-20 \\
* \text { harimals }\end{array}$ & $\begin{array}{l}1.75-2.0 \\
\text { * havi mals }\end{array}$ & $\begin{array}{l}1.75-2.0 \\
* \text { hari mals }\end{array}$ & $\begin{array}{c}1.75 \\
\text { thanimaks }\end{array}$ & $\begin{array}{c}1.75 \\
\text { *hani maks }\end{array}$ \\
\hline 7. Jumlah Jwa PerSR (Jiva) & 5 & $s$ & 5 & 5 & 5 \\
\hline 8. Jumlah Jw a Per HU ( Jiwa) & 100 & 100 & 100 & $100-200$ & 200 \\
\hline $\begin{array}{l}\text { 9. Sisa Tekan Di peryediaan } \\
\text { Dis tribusi (Meter) }\end{array}$ & 10 & 10 & 10 & 10 & 10 \\
\hline 10. Imm Operasi ( jam) & 24 & 24 & 24 & 24 & 24 \\
\hline $\begin{array}{l}\text { 11. Vobune Reservoux (\% Mar } \\
\text { Day Demand) }\end{array}$ & 15.25 & 15.25 & $15-25$ & $15 \cdot 25$ & $15=25$ \\
\hline 12. SR: HU & $\begin{array}{c}50: 50 \\
9,4 \\
80: 20\end{array}$ & $\begin{array}{l}90: 50 \\
s / d \\
80: 20\end{array}$ & $80: 20$ & $70: 30$ & $70: 30$ \\
\hline 13. Caloupan Pelayanan (\%) & 90 & 90 & 90 & 90 & 70 \\
\hline
\end{tabular}

Sumber: Kriteria Perencanaan Ditjen Cipta Karya PU, 1996

\section{B.2 Standar Penyediaan Air Non-Domestik}


Standar penyediaan air non domestik ditentukan oleh banykannya konsumen non domestik yang meliputi fasilitas seperti perkantoran, kesehatan, industri, komersial, umum, dan lainnya. Konsumsi non domestik terbagi menjadi beberapa kategori yaitu :

- Umum, meliputi : tempat ibadah, rumah sakit, sekolah, terminal, kantor dan lain sebagainya

- Komersil, meliputi : hotel, pasar, pertokoan, rumah makan dan sebagainya

- Industri, meliputi : peternakan, industri dan sebagainya

Tabel 2. Kebutuhan Air Non Domestik Untuk Kota Kategori I, II, III, IV

\begin{tabular}{|l|c|l|}
\hline \multicolumn{1}{|c|}{ SEKTOR } & NILAI & \multicolumn{1}{c|}{ SATUAN } \\
\hline Sekolah & 10 & liter/murid/hari \\
\hline Rumah Sakit & 200 & liter/bed/hari \\
\hline Puskesmas & 2000 & liter/unit/hari \\
\hline Masjid & 3000 & liter/unit/hari \\
\hline Kantor & 10 & liter/pegawai/hari \\
\hline Pasar & 12000 & liter/hektar/hari \\
\hline Hotel & 150 & liter/bed/hari \\
\hline Rumah Makan & 100 & liter/tempat duduk/hari \\
\hline Komplek Militer & 60 & liter/orang/hari \\
\hline Kawasan Industri & $0,2-0,8$ & liter/detik/hektar \\
\hline Kawasan Pariwisata & $0,1-0,3$ & liter/detik/hektar \\
\hline
\end{tabular}

Sumber: Kriteria Perencanaan Ditjen Cipta Karya PU, 1996

Tabel 3. Kebutuhan Air Non Domestik Untuk Kategori V ( Desa )

\begin{tabular}{|l|c|l|}
\hline \multicolumn{1}{|c|}{ SEKTOR } & NILAI & \multicolumn{1}{c|}{ SATUAN } \\
\hline Sekolah & 5 & liter/murid/hari \\
\hline Rum ah Sakit & 200 & liter/bed/hari \\
\hline Puskesmas & 1200 & liter/hunithari \\
\hline Masjid & 3000 & liter/unit/hari \\
\hline Mushola & 2000 & liter/unithari \\
\hline Pasar & 12000 & liter/hektar/hari \\
\hline Komer sial/Industri & 10 & liter/hari \\
\hline
\end{tabular}

Sumber: Kriteria Perencanaan Ditjen Cipta Karya PU, 1996

\section{PENYEDIAAN DAN SUMBER AIR BERSIH}

C.1 Sistem Penyediaan Air Bersih Terbatas 
Sistem ini penggunaannya untuk individual dan untuk pelayanan terbatas. Bentuk ini pada umumnya sangat sederhana mulai dari sistem yang hanya terdiri dari satu sumur atau satu sumber saja sebagai sistemnya, seperti halnya sumur - sumur yang digunakan dalam satu rumah tangga. Sampai pada suatu sistem yang apabila dilihat dari komponennya lengkap akan tetapi sistemnya kecil baik dalam bentuk maupun kapasitasnya dan dipergunakan untuk pelayanan terbatas.

\section{C.2 Sistem Penyediaan Air Bersih Komunal}

Suatu sistem penyediaan air bersih untuk komunitas yang luas atau besar atau biasa disebut dengan pelayanan perkotaan yang meliputi pelayanan domestik, pusat bisnis, perkantoran, rekreasi, pendidikan, industri, dan lain-lain.

Sistem ini pada umumnya merupakan sistem yang mempunyai kelengkapan komponen yang menyeluruh dan kadang - kadang sangat komplek, baik dilihat dari sudut teknik maupun sifat pelayanannya.

\section{C.3 Sumber Air Bersih}

Sumber air adalah keberadaan air sebagai air baku untuk air bersih bagi kebutuhan hidup manusia, hewan dan tumbuhan dalam mempertahankan kehidupannya (Chatib, 1994), sumber air yang dipergunakan untuk kebutuhan air baku diantaranya adalah Air Hujan, Air Tanah, dan Air Permukaan.

Pada dasarnya Kabupaten Karo memiliki \pm 53 sumber mata air (lihat Tabel dibawah) yang terdata dengan debit total $\pm 14.275,87 \mathrm{ltr} / \mathrm{dt}$ dengan rincian yang bersumber dari mata air sebesar $\pm 1.271,23 \mathrm{ltr} / \mathrm{dt}$ dan yang bersumber dari air permukaan sebesar \pm 13.592,00 ltr/dt, namun yang telah dimaanfaatkan (terpasang) masih \pm 587,37 ltr/dt, seperti dalam tabel dibawah ini. Sumber mata air tersebut terdapat di 15 Kecamatan, 2 Kecamatan (Simpang Empat dan Merdeka) tidak memiliki sumber mata air maupun sungai.

Tabel 4. Sumber Air Baku Kabupaten Karo

\begin{tabular}{|r|l|r|l|r|r|r|r|}
\hline \multirow{2}{*}{ No } & \multirow{2}{*}{ Kecamatan } & \multicolumn{5}{|c|}{ Sumber Air Baku } \\
\cline { 3 - 8 } & & \multicolumn{1}{|c|}{ Jenis } & Desa/Nama & Elevasi & \multicolumn{2}{|c|}{ Koordinat } & Q(L/dt) \\
\hline 1 & Mardingding & Mata Air & Lau Kapur & 209 & 389878 & 357954 & 8.182 \\
\hline 2 & Lau Baleng & Mata Air & Lau Marpar & 374 & 400661 & 340417 & 22.905 \\
\hline
\end{tabular}


Jurnal Visi Eksakta (JVIEKS)

Vol.2, No.2, Juli 2021, pp. 225-238

https://ejournal.uhn.ac.id/index.php/eksakta

\begin{tabular}{|c|c|c|c|c|c|c|c|}
\hline \multirow{3}{*}{ No } & \multirow{3}{*}{ Kecamatan } & \multicolumn{6}{|c|}{ Sumber Air Baku } \\
\hline & & \multirow[t]{2}{*}{ Jenis } & \multirow{2}{*}{$\begin{array}{l}\text { Desa/Nama } \\
\text { Lau Giring-giring }\end{array}$} & \multirow{2}{*}{$\begin{array}{r}\text { Elevasi } \\
294 \\
\end{array}$} & \multicolumn{2}{|c|}{ Koordinat } & \multirow{2}{*}{$\frac{\mathrm{Q}(\mathrm{L} / \mathrm{dt})}{12.609}$} \\
\hline & & & & & 400246 & 340861 & \\
\hline \multirow[t]{3}{*}{3} & Tiga Binanga & Mata Air & Gunung Manumpak-I & 731 & 424469 & 338893 & 19.429 \\
\hline & & & Gunung Manumpak-II & 706 & 424093 & 339152 & 7.065 \\
\hline & & & Gunung Manumpak-III & 728 & 424462 & 338879 & 22.961 \\
\hline \multirow[t]{5}{*}{4} & Juhar & Mata Air & Lau Negri I & 821 & 425478 & 334353 & 1.373 \\
\hline & & & Lau Negri II & 783 & 424418 & 334334 & 3.974 \\
\hline & & & Lau Negri III & 780 & 424367 & 334337 & 0.772 \\
\hline & & & Lau Negri IV & 780 & 424354 & 334356 & 0.772 \\
\hline & & & Lau Toran & 980 & 419183 & 328368 & 19.428 \\
\hline \multirow[t]{2}{*}{5} & Munte & Mata Air & Lau Siolioli & 914 & 430327 & 337556 & 9.42 \\
\hline & & Air Baku & Lau Sibulan & 1412 & 441738 & 329690 & 20.325 \\
\hline \multirow[t]{4}{*}{6} & Kuta Buluh & Air Baku & Lau Nggalam & 1556 & 419906 & 355595 & 19.429 \\
\hline & & & Lau Rakit I & 1624 & 420541 & 355941 & 9.4 \\
\hline & & & Lau Rakit II & 1524 & 420330 & 355258 & 7.9 \\
\hline & & & Lau Rakit III & 1660 & 420907 & 356411 & 10.99 \\
\hline 7 & Payung & Mata Air & Lau Naga & 902 & 429259 & 345076 & 8.279 \\
\hline 8 & Tiga Nderket & Sungai & Lau Makam & 1055 & 428703 & 349783 & 427.389 \\
\hline \multirow[t]{2}{*}{9} & Naman Teran & Mata Air & Lau Diden I & 1381 & 439637 & 354599 & 8.635 \\
\hline & & & Lau Tupin & 1417 & 432755 & 353355 & 8.831 \\
\hline \multirow[t]{9}{*}{10} & Kabanjahe & Mata Air & Lau Bawang I & 1164 & 443574 & 341525 & 40 \\
\hline & & & Lau Bawang II & 1164 & 443574 & 341525 & 45 \\
\hline & & & Lau Melas I (Tirtanadi) & 1268 & 447769 & 350303 & 25 \\
\hline & & & Lau Melas II & 1268 & 447769 & 350303 & 15 \\
\hline & & & Lau Peceren & 1377 & 446691 & 353014 & 10 \\
\hline & & & Lau Banjar & 1985 & 441656 & 336110 & 20 \\
\hline & & & Lau Berneh & 1183 & 443059 & 343283 & 35 \\
\hline & & Air Baku & Lau Biang & 1138 & 443804 & 341530 & 12955.6 \\
\hline & & & Lau Tupin & 1268 & 447769 & 350303 & 637.256 \\
\hline \multirow[t]{5}{*}{11} & Tiga Panah & Mata Air & Mulia Rakyat I & 1331 & 456977 & 345018 & 9.42 \\
\hline & & Air Baku & Lau Riman I & 1381 & 441715 & 329698 & 5.103 \\
\hline & & & Mulia Rakyat II & 1290 & 448043 & 332585 & 7.065 \\
\hline & & & Mulia Rakyat III & 1290 & 448059 & 332577 & 10.99 \\
\hline & & & Lau Riman II & 1412 & 441738 & 329690 & 7.948 \\
\hline \multirow[t]{2}{*}{13} & Dolat Rakyat/ & Mata Air & Lau Seruwai I & 1420 & 450504 & 355500 & 9.813 \\
\hline & Berastagi & & & & & & \\
\hline
\end{tabular}

Received, 22 ${ }^{\text {rd }}$ April 2021; 28 ${ }^{\text {th }}$ May Revised, 2021; Accepted July, 2021 


\begin{tabular}{|r|l|l|l|r|r|r|r|}
\hline \multirow{2}{*}{ No } & \multirow{2}{*}{ Kecamatan } & \multicolumn{6}{|c|}{ Sumber Air Baku } \\
\cline { 3 - 8 } & & Jenis & Desa/Nama & Elevasi & \multicolumn{2}{c|}{ Koordinat } & Q(L/dt) \\
\hline & & & Lau Seruwai II & 1302 & 449390 & 351336 & 100.867 \\
\hline & & & Tambak Mbelang & 1465 & 450071 & 354343 & 15.896 \\
\hline 14 & Merek & Air Baku & Aek Baluren & 1543 & 440256 & 322672 & 122.896 \\
\hline 15 & Barusjahe & Air Baku & Lau Badigulan I & 1331 & 456977 & 345018 & 14.13 \\
\hline & & & Lau Badigulan II & 1325 & 456897 & 345012 & 8.635 \\
\hline
\end{tabular}

Sumber: Buku Putih Sanitasi Kabupaten Karo Tahun 2011

\section{METODE PENELITIAN}

Penelitian ini berlokasi di Kabupaten Karo dimana wilayah yang ditinjau adalah 17 kecamatan di kabupaten tersebut. Beberapa tahapan penelitian secara rinci dapat dilihat sebagai berikut

- Tinjauan Pustaka

- Pengumpulan Data (Primer dan Sekunder)

- Pengolahan Data

- Analisis dan Pembahasan

Data yang dikumpulkan adalah data jumlah penduduk Kabupaten Karo terbaru, fasilitasfasilitas umum, data geografis, peta adminitrasi, data iklim, dan data curah hujan bulanan. Akan tetapi data yang terpenting didalam memproyeksikan kebutuhan air adalah data jumlah penduduk dan data curah hujan bulanan.

Tabel 5 Data Penduduk Kabupaten Karo Tahun 2012-2017

\begin{tabular}{|c|l|c|c|c|c|c|c|}
\hline \multirow{2}{*}{ No } & \multirow{2}{*}{ Kecamatan } & \multicolumn{6}{|c|}{ Jumlah Penduduk (Tahun) } \\
\cline { 3 - 8 } & & 2012 & 2013 & 2014 & 2015 & 2016 & 2017 \\
\hline 1 & Mardingding & 17.445 & 17.684 & 18.601 & 18.940 & 19.281 & 19.363 \\
\hline 2 & Laubaleng & 18.110 & 18.359 & 19.391 & 19.766 & 20.099 & 20.210 \\
\hline 3 & Tigabinanga & 20.346 & 20.626 & 21.329 & 21.763 & 22.108 & 22.238 \\
\hline 4 & Juhar & 13.540 & 13.726 & 13.877 & 14.090 & 14.384 & 14.406 \\
\hline 5 & Munte & 20.127 & 20.404 & 20.672 & 20.949 & 21.428 & 21.415 \\
\hline 6 & Kutabuluh & 10.823 & 10.972 & 11.124 & 11.327 & 11.531 & 11.569 \\
\hline 7 & Payung & 11.079 & 11.232 & 11.601 & 11.812 & 12.024 & 12.076 \\
\hline
\end{tabular}




\begin{tabular}{|c|l|c|c|c|c|c|c|}
\hline 8 & Tiganderket & 13.474 & 13.659 & 13.757 & 14.078 & 14.260 & 14.390 \\
\hline 9 & Simpang Empat & 19.440 & 19.707 & 20.009 & 20.373 & 20.739 & 20.820 \\
\hline 10 & Naman Teran & 13.083 & 13.263 & 13.951 & 13.985 & 14.460 & 14.286 \\
\hline 11 & Merdeka & 13.607 & 13.794 & 15.158 & 15.244 & 15.712 & 15.580 \\
\hline 12 & Kabanjahe & 64.746 & 65.635 & 70.890 & 72.246 & 73.687 & 73.810 \\
\hline 13 & Berastagi & 43.494 & 44.091 & 48.050 & 48.975 & 49.805 & 50.061 \\
\hline 14 & Tigapanah & 29.976 & 30.388 & 32.500 & 33.207 & 33.687 & 33.932 \\
\hline 15 & Dolat Rayat & 8.482 & 8.599 & 9.047 & 9.212 & 9.378 & 9.415 \\
\hline 16 & Merek & 18.458 & 18.712 & 19.655 & 20.109 & 20.373 & 20.543 \\
\hline 17 & Barusjahe & 22.593 & 22.904 & 23.010 & 23.515 & 23.850 & 24.038 \\
\hline & Jumlah & 338.696 & 363.755 & 382.622 & 389.591 & 396.806 & 398.152 \\
\hline
\end{tabular}

Sumber : Badan Pusat Statistik 2018

Berdasarkan catatan Stasiun Klimatologi Kuta Gadung Kabupaten Karo, pada tahun 2010 terdapat 155 hari hujan dengan volume curah hujan sebanyak $1.719 \mathrm{~mm}$. Curah hujan terbesar terjadi pada bulan Nopember yaitu $268 \mathrm{~mm}$ dengan hari hujan sebanyak 21 hari. Sedangkan curah hujan terkecil terjadi pada bulan januari sebesar $64 \mathrm{~mm}$ dan jumlah hari hujan terkecil pada bulan Pebruari sebanyak 7 hari. Banyaknya curah hujan dikabupaten karo dapat dilihat pada tabel berikut

Tabel 6. Curah Hujan dan Banyaknya Hari Hujan di Kabupaten Karo

\begin{tabular}{|c|l|c|c|}
\hline No & Bulan & $\begin{array}{c}\text { Curah Hujan } \\
(\mathrm{mm})\end{array}$ & Hari Hujan \\
\hline 1 & Januari & 64 & 11 \\
\hline 2 & Pebruari & 105 & 7 \\
\hline 3 & Maret & 109 & 12 \\
\hline 4 & April & 108 & 12 \\
\hline 5 & Mei & 79 & 10 \\
\hline 6 & Juni & 181 & 16 \\
\hline 7 & Juli & 168 & 15 \\
\hline 8 & Agustus & 183 & 13 \\
\hline 9 & September & 160 & 13 \\
\hline
\end{tabular}




\begin{tabular}{|c|l|c|c|}
\hline 10 & Oktober & 91 & 11 \\
\hline 11 & Nopember & 268 & 21 \\
\hline 12 & Desember & 203 & 14 \\
\hline jumlah & 1.719 & 155 \\
\hline
\end{tabular}

Sumber: Karo Dalam Angka 2012

\section{E. ANALISIS DAN HASIL}

E.1 Proyeksi Penduduk

Dari hasil perhitungan proyeksi penduduk Kabupaten Karo untuk tahun 2027, didapatkan bahwa tahun 2017 bertambah jiwa penduduk sejumlah 496.462 orang. Dengan demikian bertambah 137.639 jiwa dari tahun 2012, atau laju pertumbuhannya yaitu 1,92\%.

Tabel 7 Metode Proyeksi Penduduk (Aritmatika)

\begin{tabular}{|c|c|c|c|c|c|c|}
\hline \multirow{2}{*}{ No } & \multirow{2}{*}{ Kecamatan } & \multicolumn{3}{|c|}{ Proyeksi Penduduk (jiwa) } & \multirow{2}{*}{ Laju r (\%) } \\
\cline { 3 - 6 } & & 2012 & 2017 & 2022 & 2027 & \\
\hline 1 & Mardingding & 17.445 & 19.363 & 21.492 & 23.856 & 2,11 \\
\hline 2 & Laubaleng & 18.110 & 20.210 & 22.554 & 25.170 & 2,22 \\
\hline 3 & Tigabinanga & 20.346 & 22.238 & 24.306 & 26.566 & 1,81 \\
\hline 4 & Juhar & 13.540 & 14.406 & 15.327 & 16.307 & 1,25 \\
\hline 5 & Munte & 20.127 & 21.415 & 22.785 & 24.243 & 1,25 \\
\hline 6 & Kutabuluh & 10.823 & 11.569 & 12.367 & 13.220 & 1,36 \\
\hline 7 & Payung & 11.079 & 12.076 & 13.162 & 14.346 & 1,74 \\
\hline 8 & Tiganderket & 13.474 & 14.390 & 15.368 & 16.413 & 1,33 \\
\hline 9 & Simpang Empat & 19.440 & 20.820 & 22.298 & 23.881 & 1,39 \\
\hline 10 & Naman Teran & 13.083 & 14.286 & 15.600 & 17.035 & 1,79 \\
\hline 11 & Merdeka & 13.607 & 15.580 & 17.839 & 20.425 & 2,75 \\
\hline 12 & Kabanjahe & 64.746 & 73.810 & 84.143 & 95.923 & 2,67 \\
\hline 13 & Berastagi & 43.494 & 50.061 & 57.620 & 66.320 & 2,86 \\
\hline 14 & Tigapanah & 29.976 & 33.932 & 38.411 & 43.481 & 2,52 \\
\hline 15 & Dolat Rayat & 8.482 & 9.415 & 10.450 & 11.599 & 2,12 \\
\hline
\end{tabular}




\begin{tabular}{|c|c|c|c|c|c|c|}
\hline \multirow{2}{*}{ No } & \multirow{2}{*}{ Kecamatan } & \multicolumn{3}{|c|}{ Proyeksi Penduduk (jiwa) } & \multirow{2}{*}{ Laju r (\%) } \\
\cline { 3 - 6 } & & 2012 & 2017 & 2022 & 2027 & \\
\hline 16 & Merek & 18.458 & 20.543 & 22.864 & 25.447 & 2,18 \\
\hline 17 & Barusjahe & 22.593 & 24.038 & 25.576 & 27.212 & 1,25 \\
\hline \multicolumn{2}{|c|}{ Total } & 358.823 & 398.152 & 442.162 & 496.462 & \\
\hline
\end{tabular}

Kota Kabanjahe sebagai Ibukota Kabupaten Karo ditetapkan sebagai Pusat Kegiatan Lokal (PKL) diarahkan sebagai kawasan pusat pemerintahan, pendidikan, kesehatan, perdagangan dan jasa, kawasan agroindustri dan pengolahan hasil pertanian dan holtikultura. Salah satu contoh proyeksi kebutuhan air bersih yitu untuk Kecamatan Kabanjahe proyeksi kebutuhan airnya dari tahun 2017-2027 dapat dilihat pada tabel berikut ini :

Tabel 8 Proyeksi Kebutuhan Air Kec.Kabanjahe Tahun 2017-2027

\begin{tabular}{|l|l|l|c|c|c|}
\hline \multirow{2}{*}{ No Uraian } & \multirow{2}{*}{ Satuan } & \multicolumn{3}{c|}{ Tahun Proyeksi } \\
\cline { 4 - 6 } & & & 2017 & 2022 & 2027 \\
\hline 1 & Total Penduduk Administratif & Jiwa & 73.810 & 84.143 & 95.923 \\
\hline 2 & Penduduk Areal Pelayanan & Jiwa & 73.810 & 84.143 & 95.923 \\
\hline 3 & Jumlah Desa/ Kelurahan & & 8 & 8 & 8 \\
\hline 4 & Cakupan Pelayanan & $\%$ & 80 & 90 & 100 \\
\hline 5 & Penduduk yang Dilayani & Jiwa & 59048 & 75728.7 & 95923 \\
\hline 6 & Perbandingan SR : HU & $\%$ & $80 \%: 20 \%$ & $90 \%: 10 \%$ & $100 \%$ \\
\hline 7 & Penduduk Dilayani SR & Jiwa & 47238.4 & 68155.83 & 95923 \\
\hline 8 & Penduduk Dilayani HU & Jiwa & 11809.6 & 7572.87 & 0 \\
\hline 9 & Kebutuhan Air Per Kapita untuk SR & ltr/org/hari & 120 & 120 & 120 \\
\hline 10 & Kebutuhan Air Per Kapita untuk HU & ltr/org/hari & 40 & 40 & 40 \\
\hline 11 & Kebutuhan Air Rumah Tangga & ltr/dt & 71.08 & 98.17 & 133.23 \\
\hline 12 & $\begin{array}{l}\text { Kebutuhan Air Non Domestik 40 } \\
\text { liter }\end{array}$ & ltr/dt & 23.46 & 32.40 & 43.96 \\
\hline 13 & Jumlah Kebutuhan Air & ltr/dt & $\mathbf{9 4 . 5 3}$ & $\mathbf{1 3 0 . 5 6}$ & $\mathbf{1 7 7 . 2 0}$ \\
\hline 14 & $\begin{array}{l}\text { Kebutuhan Air Hari Maksimum } \\
\text { (F=1,15) }\end{array}$ & ltr/dt & 108.71 & 150.15 & 203.77 \\
\hline 15 & Jumlah Orang per SR & & 6 & 5 & 4 \\
\hline 16 & Jumlah SR & Unit & 7873.07 & 13631.17 & 23980.75 \\
\hline 17 & Jumlah Orang per HU & & 60 & 50 & 40 \\
\hline 18 & Jumlah HU & Unit & 196.83 & 151.46 & 0 \\
\hline
\end{tabular}


Dari hasil perhitungan proyeksi kebutuhan air ibu kota kabupaten Karo didapatkan kebutuhan air pada tahun 2027 yaitu sebesar 177.20 ltr/det. Demikian juga didapatkan proyeksi kebutuhan air untuk kecamatan-kecamatan yang lain di Kabupaten Karo seperti pada tabel berikut :

Tabel 9 Rekapitulasi Proyeksi Kebutuhan Air Berdasarkan Kecamatan Tahun 2027

\begin{tabular}{|c|l|c|c|c|}
\hline \multirow{2}{*}{ No } & \multirow{2}{*}{ Kecamatan } & \multicolumn{3}{|c|}{ Proyeksi Kebutuhan Air (ltr/det) } \\
\cline { 3 - 5 } & & 2017 & 2022 & 2027 \\
\hline 1 & Mardingding & 24,52 & 33,35 & 44,07 \\
\hline 2 & Laubaleng & 25,88 & 34,99 & 46,50 \\
\hline 3 & Tigabinanga & 28,48 & 37,71 & 49,07 \\
\hline 4 & Juhar & 18,45 & 23,78 & 30,12 \\
\hline 5 & Munte & 27,42 & 34,70 & 44,78 \\
\hline 6 & Kutabuluh & 14,82 & 19,19 & 24,42 \\
\hline 7 & Payung & 15,46 & 20,42 & 26,50 \\
\hline 8 & Tiganderket & 18,43 & 23,84 & 30,31 \\
\hline 9 & Simpang Empat & 26,67 & 34,60 & 44,11 \\
\hline 10 & Naman Teran & 18,29 & 24,20 & 31,47 \\
\hline 11 & Merdeka & 19,95 & 27,68 & 37,73 \\
\hline 12 & Kabanjahe & 94,53 & 130,56 & 177,19 \\
\hline 13 & Berastagi & 64,11 & 89,41 & 122,51 \\
\hline 14 & Tigapanah & 43,46 & 59,60 & 80,31 \\
\hline 15 & Dolat Rayat & 11,71 & 16,22 & 21,42 \\
\hline 16 & Merek & 26,31 & 35,47 & 47,0 \\
\hline 17 & Barusjahe & 30,79 & 39,69 & 50,26 \\
\hline & & $\mathbf{5 0 9 , 2 8}$ & $\mathbf{6 8 5 , 4 1}$ & $\mathbf{9 0 7 , 7 7}$ \\
\hline
\end{tabular}

Tabel 10 Kebutuhan Air Masyarakat Kabupaten Karo 2027

\begin{tabular}{|c|c|c|c|c|c|}
\hline \multirow{2}{*}{ No } & Kecamatan & Jumlah & Debit & Debit & Debit Total(Qt) \\
& & Penduduk & Kebutuhan & Kebutuhan Air & Qt = Qd + Qn \\
& & Air Domestik & Non Domestik & $(1 / \mathrm{dtk})$ \\
\hline
\end{tabular}




\begin{tabular}{|l|l|c|c|c|c|}
\hline & & $(\mathrm{Qd})$ & $(\mathrm{Qn})$ & \\
& & & $(1 / \mathrm{dtk})$ & $1 / \mathrm{dtk})$ & \\
\hline 1 & Mardingding & 23.856 & 33.133 & 10.934 & 44.067 \\
\hline 2 & Laubaleng & 25.170 & 34.958 & 11.536 & 46.494 \\
\hline 3 & Tigabinanga & 26.566 & 36.897 & 12.176 & 49.073 \\
\hline 4 & Juhar & 16.307 & 22.648 & 7.474 & 30.122 \\
\hline 5 & Munte & 24.243 & 33.670 & 11.111 & 44.782 \\
\hline 6 & Kutabuluh & 13.220 & 18.361 & 6.059 & 24.420 \\
\hline 7 & Payung & 14.346 & 19.925 & 6.575 & 26.500 \\
\hline 8 & Tiganderket & 16.413 & 22.795 & 7.522 & 30.318 \\
\hline 9 & Simpang Empat & 23.881 & 33.168 & 10.945 & 44.113 \\
\hline 10 & Naman Teran & 17.035 & 23.659 & 7.807 & 31.467 \\
\hline 11 & Merdeka & 20.425 & 28.368 & 9.361 & 37.729 \\
\hline 12 & Kabanjahe & 95.923 & 133.226 & 43.964 & 177.191 \\
\hline 13 & Berastagi & 66.320 & 92.111 & 30.396 & 122.507 \\
\hline 14 & Tigapanah & 43.481 & 60.390 & 19.928 & 80.319 \\
\hline 15 & Dolat Rayat & 11.599 & 16.109 & 5.316 & 21.425 \\
\hline 16 & Merek & 25.447 & 35.343 & 11.663 & 47.006 \\
\hline 17 & Barusjahe & 27.212 & 37.794 & 12.472 & 50.266 \\
\hline Jumlah & 491.444 & 682.555 & 225.239 & 907.799 \\
\hline
\end{tabular}

Maka, kebutuhan total air bersih sampai 2027 adalah jumlah keseluruhan air bersih domestik dan non domestik yaitu :

$$
\begin{aligned}
& =682.555+225.239 \\
& =907,80 \mathrm{ltr} / \mathrm{det}
\end{aligned}
$$

\section{KESIMPULAN}

Berdasarkan hasil proyeksi jumlah penduduk ditambah dengan jumlah kebutuhan air pada tahun 2027 sebanyak 491.444 jiwa debit air yang dibutuhkan sebesar 907 1/dtk 
sedangkan kapasitas produksi saat ini sebesar 14.744 1/dtk, sehingga kebutuhan air minum untuk kabupaten karo dapat terpenuhi dari sumber air permukaan yang ada.

\section{DAFTAR PUSTAKA}

Indra Kusuma Sari, Lily Montarich Limantara serta Dwi Priyantoro (2007). Analisa Ketersediaan dan Kebutuhan Air Pada DAS, Kabupaten Situbondo.

Marhadiyanto D. D dan Sumprihandto N, Studi Pemenuhan Keburuhan Air Bersih Dengan Sistem Penampungan Air Hujan.

Pranoto Samto Admodj, Sri Sangkawati(2008), Evaluasi dan Prediksi Pengolahan Jaringan Air Bersih IKK, Kabupaten Kendal.

Susana dan Eddy Setiadi Soedjono. Penyediaan Air Bersih, Pulau Banggai Sulawesi Tengah. Sumber Tabel : Direktorat Jendral Cipta Karya, Departemen Pekerjaan Umum 1996

Sumber : Buku Putih Sanitasi Kabupaten Deli Serdang Tahun 2011

Sumber : Bdan Pusat Statistik dalam Angka 2018

Wayan Sutapa(februari 2009). Studi Potensi Pengembangan Sumber Daya Air, Sulawesi Tengah Sumber : Buku Putih Sanitasi Kabupaten Deli Serdang Tahun 2011 